\title{
Lanskap Arkeologi Situs Gosari-Gresik dalam Perspektif Prosesual dan Pasca-Prosesual
}

\author{
Laksmi Eko Safitri
}

Prodi Magister Arkeologi Universitas Gadjah Mada Yogyakarta

Correspondence:

Laksmi Eko Safitri

Prodi Magister Arkeologi Universitas Gadjah Mada Yogyakarta

laksmiesnu@gmail.com

Article History:

Received 11 August 2020

Revised 25 April 2021

Accepted 27 April 2021

\begin{abstract}
In this paper, the Gosari-Gresik Site is categorized as one of the archaeological artifacts of the archipelago that provides information related to the past. The site is understood as a representation from a Processual and Post-Processual perspective. The scope of this paper presents the Gosari Site landscape as a representation of the processual and post-processual paradigms. The contradictions of the two paradigms above are synergized to determine the landscape of the Gosari Site, which consists of former pottery burning stoves, springs, and inscriptions. In that case the first paradigm describes the date or age of the site, the type or model of pottery produced; correlation between archaeological elements; and the role or the pottery industry during the Majapahit era. Meanwhile, the second paradigm is used to complement the analysis that the previous paradigm could not reach, especially regarding the interpretation of sendang in the view of the local community based on the oral-tradition/folklore that they believe. From the two paradigms, the conclusion is that the position of the sendang has an important role, both in the pottery industry and in the life of the surrounding community. In addition, it is known that the intangible cultural heritage of the classical period is still being preserved.

Keywords:

Gosari, lanscape processual, post-processual
\end{abstract}

\section{Abstrak}

Dalam tulisan ini Situs Gosari-Gresik dikategorikan sebagai salah satu artefak arkeologis Nusantara yang memberikan informasi terkait masa silam. Situs tersebut dipahami sebagai representasi dari perspektif Prosesual dan PascaProsesual. Ruang lingkup tulisan ini menyajikan lanskap Situs Gosari sebagai representasi dari paradigma prosesual dan pasca-prosesual. Kontradiksi kedua paradigma di atas disinergikan untuk mengetahui lanskap Situs Gosari yang terdiri dari bekas tungku pembakaran gerabah, sendang, dan prasasti. Dalam hal itu paradigma pertama menjelaskan tarikh atau usia situs, jenis atau model gerabah yang dihasilkan; korelasi antarunsur arkeologi; dan peranan atau industri gerabah pada masa Majapahit. Sedangkan paradigma kedua digunakan untuk melengkapi analisis yang tidak dapat dijangkau paradigma sebelumnya, terutama terkait interpretasi terhadap sendang dalam pandangan masyarakat setempat berdasarkan tradisi lisan/folklor yang diyakini. Dari kedua paradigma tersebut dihasilkan kesimpulan bahwa kedudukan sendang memiliki peranan penting, baik dalam industri gerabah maupun kehidupan masyarakat sekitar. Selain itu, diketahui bahwa tinggalan budaya tak bendawi masa klasik tersebut masih dipelihara.

Kata Kunci:

Gosari, lanskap, prosesual, pasca-prosesual 


\section{Pendahuluan}

Dalam kajian arkeologi lanskap dikategorikan sebagai sebuah pendekatan 'tematik' yang diserap dari perspektif dan kerangka pikir disiplin lain untuk menyelesaikan persoalan-persoalan arkeologi. Pendekatan yang menjadikan lanskap sebagai upaya dalam menyelesaikan persoalanpersoalan arkeologi berkembang menjadi salah satu bidang kajian khusus yang kelak dikenal sebagai arkeologi lanskap (Sunliensyar, 2018). Pada dasarnya, kehadiran arkeologi lanskap tidak dapat dilepaskan dari perkembangan ilmu arkeologi. Pada mulanya, kajian lanskap lahir dari semangat pemikiran prosesual yang dimulai dari penggunaan metode ilmiah sebagaimana yang berkembang dalam ilmu-ilmu alam untuk menjelaskan proses budaya di masa lalu dan terus berkembang pada era pasca-prosesual (Webster, 2008).

Kerangka konseptual yang ditawarkan dalam pendekatan prosesual mendapatkan kritik dari sebagian kalangan yang merasa tidak puas dengan metodeyangdigunakan.Pandanganinimunculpada tahun 1980-an yang diawali banyaknya tulisantulisan yang mengapresiasikan ketidaksetujuan terhadap prosesual. Pandangan ini kemudian dikenal sebagai pasca-prosesual (Winarto, 2014). Hodder (1991b, 1991a) mengungkapkan, salah satu kritik terkait metode prosesual dalam arkeologi seputar pandangan budaya materi sebagai hasil dari proses adaptif jangka panjang dan alat untuk meresponlingkungan. Artinya, budaya materi tidak semata-mata ciptaan manusia tetapi sebagai hasil proses adaptasi manusia terhadap lingkungan. Sebaliknya, pasca-prosesual menganggap budaya materi bersifat aktif. Artinya, budaya materi diciptakan, digunakan dan dimanipulasi oleh manusia untuk memicu terjadinya perubahan sosial.

Kehadiran paradigma prosesual dan pasca- prosesual dalam khazanah kajian arkeologi berpengaruh secara langsung terhadap kajian lanskap. Dua paradigma yang saling bertentangan ini, memiliki pemahaman yang berbeda mengenai arkeologi lanskap. Hal ini seringkali menimbulkan ambiguitas dalam memahami lanskap itu sendiri (Gosden \& Head, 1994). Di sisi lain, kehadiran pendekatan lanskap tersebut menimbulkan kekeliruan dalam menempatkan posisi arkeologi lanskap dengan kajian arkeologi lain, misalnya dengan arkeologi lingkungan, arkeologi spasial, dan arkeologi permukiman (Sunliensyar, 2018).

Namun dalam perkembangan berikutnya, kontradiksi perspektif prosesual dan pascaprosesual tidak begitu dipersoalkan. Yang lebih pentingdalam sebuah penelitian arkeologis adalah kemampuan arkeolog untuk mengintegrasikan kedua perspektif tersebut dalam menganalisis materi arkeologi. Semakin banyak data yang diperoleh dari berbagai perspektif, maka validitas hasil penelitian semakin kuat. Sehingga tujuan studi arkeologi sebagai upaya merekontruksi kehidupan masa lalu, semakin mendekati kebenarannya (Mundardjito, 2007).

Sebagai bentuk pemahaman lebih lanjut terhadap kedua perspektif tersebut, kajian ini akan membahas bagaimana prosesual dan pascaprosesual memandang lanskap arkeologi Situs Gosari di Desa Gosari Kecamatan Ujungpangkah Kabupaten Gresik (selanjutnya disebut Situs Gosari). Adapun alasan Situs Gosari menjadi obyek penelitian ini adalah kondisi alam kedudukan situs yang sebagian berada di bukit kapur dan dataran rendah, serta korelasinya dengan kondisi saat ini yang dekat dengan areal pertambangan dan permukiman warga. Selain itu, tinggalan arkeologi berupa bekas tungku pembakaran, sendang, prasasti Gosari (prasasti butulan), dan sebaran fragmen gerabah, keramik, lumpang di sekitar permukiman warga (Utomo, 2012), 
tentunya menarik untuk dikaji dalam paradigma studi arkeologi lanskap dengan menggunakan perspektif prosesual dan pasca-prosesual. Ruang lingkup penelitian ini hanyalah membahas perbedaan lanskap dalam perspektif prosesual dan pasca-prosesual. Selanjutnya, bangaimana kedua paradigma tersebut memberi pemahaman terhadap lanskap Situs Gosari.

\section{Metode Penelitian}

Penelitian ini merupakan penelitian kualitatif yang berbentuk analisis deskriptif. Diawali dengan pengumpulan data sekunder yang diperoleh dari studi kepustakaan terhadap "Laporan Penelitian Arkeologi Teknologi Industri Gerabah Halus di Wilayah Ujung Pangkah Gresik Jawa Timur" oleh Tim Peneliti Pusat Penelitian dan Pengembangan Arkeologi Nasional tahun (Peneliti, 2005, 2006, 2009); dan data primer melalui pengamatan langsung dan wawancara terkait kondisi situs tersebut. Data tersebut kemudian dianalisis secara deskriptif menggunakan penalaran induktif. Selanjutnya, hasil analisis diinterpretasikan berdasarkan perspektif prosesual dan pascaprosesual. Sehingga dihasilkan pemaknaan atau interpretasi terkait kondisi lanskap Situs Gosari.

\section{Hasil dan Pembahasan}

\section{Lanskap dalam Paradigma Prosesual}

Arkeologi prosesual merupakan pembaharuan dalam kajian arkeologi yang muncul pada dekade 1940-an sebagai reaksi ketidakpuasan terhadap pemikiran arkeologi tradisional. Fokus kajian tradisional biasanya menempatkan materi arkeologi pada konteks ruang dan waktu melalui analisis yang hati-hati dan klasifikasi artefak, yang diperoleh dari hasil ekskavasi, lalu dikritik oleh arkeolog lain. Walter W. Taylor mengkritik langgam tersebut dan menyatakan bahwa seorang arkeolog seharusnya menganalisis material yang ditemukannya lantas menemukan fungsi dari material yang dikaji, bukan semata menempatkan objek material tersebut dalam konteks waktu dan spasial (Hudson, 2008; Sabloff, 2005; Sunliensyar, 2018). Hal iniberdampakbesarpada perkembangan kegiatan arkeologis. Pengumpulan dan perekaman data secara menyeluruh pada sebuah situs tidak serta merta dapat mengungkapkan seluruh aspekaspek kebudayaan melainkan hanya aspek-aspek kecil dari satu sub-sistem budaya. Untuk itu diperlukan strategi dan metode yang baik dalam pengambilan sampel sehingga dari sampel tersebut seorang arkeolog mampu menarik kesimpulan yang meyakinkan tentang sistem kebudayaan masa lalu secara menyeluruh berdasarkan pengetahuan parsial mereka (Sabloff, 2005).

Paradigma prosesualis menganggap bahwa kebudayaan bersifat pasif(Earle etal., 1987; Hodder, 2005). Maksudnya, ideologi dan perilaku manusia maupun budaya materi yang diciptakannya dibentuk oleh lingkungan alam dan sosial. Sebagai contoh, perahu dibuat oleh manusia yang umumnya tinggal di kawasan sungai-sungai besar, danau dan pesisir pantai dengan tujuan untuk memudahkan mobilitas. Perahu dan alat transportasi air lainnya tidak akan dibuat oleh manusia yang hidup di gurun dan sabana. Oleh karena itu, lanskap dalam pandangan mereka adalah entitas yang terdiri dari unsur-unsur fisik semata. Keberadannya bukan hal yang abstrak tetapi benar-benar bisa diamati dalam konteksnya. Unsur fisik tersebut berupa fitur-fitur yang terbentuk secara alamiah maupun yang dimodifikasi dan dibentuk oleh manusia (Sunliensyar, 2018).

Binford menyusun beberapa kata kunci penting dalam paradigma prosesual (Sabloff, 2005; Sunliensyar, 2018). Pertama, budaya dilihat sebagai sebuah sistem dengan aspek teknologi, ekonomi, politik dan ideologi yang saling terkait satu sama lain. Kedua, menekankan pentingnya 
ekologi kultural, dan pentingnya melihat interaksi lingkungan dan budaya secara sistemik terutama hubungan antara lingkungan dan teknologi. Ketiga, Binford berargumen bahwa arkeolog harus mempelajari evolusi sistem budaya sepanjang waktu untuk menghasilkan narasi umum (general narrative).

Prosesual menekankan bahwa perubahan budaya dilihat sebagai sebuah sistem yang beradaptasi dengan lingkungannya. Perbedaan budaya bendawi karena terdapat perbedaan lingkungan. Oleh karena itu kajian prosesual bersifat materialistik dan cenderung mengarah ke bidang sains dengan metode deduktif. Pokok dari metodologi arkeologi harus menjadi hipotesis yang teruji (Greene, 2003; Wylie, 2002). Pandangan kaum prosesual terhadap hubungan antara budaya material dan perilaku manusia dengan lingkungannya tentunya berdampak pada pemahaman mereka terhadap lanskap. Lanskap diartikan sebagai bentang alam dari suatu wilayah yang merupakan bagian dari berbagai komponen baik alam maupun binaan (Gosden \& Head, 1994; Tanudirjo, 2019).

Merujuk dari pemahaman prosesual yang bersifat materialistik, tentu saja kajian-kajian terhadap lanskap menitikberatkan pada unsurunsur fisik baik alami maupun binaan seperti candi, gunung, bekas pertambangan, dan sebagainya. Menurut Tanudirjo (2019) kajian lanskap dalam paradigma prosesual akan fokus membahas diantaranya tentang: (1) unsur-unsur alam dan budaya, (2) hubungan antar unsur, (3) pengaruh unsur alam terhadap budaya, dan (4) menjelaskan hubungan antar unsur alam dan pengaruh budaya. Pada perkembangannya, kajian lanskap dalam paradigma prosesual memunculkan kajian-kajian seperti arkeologi spasial, arkeologi lingkungan, arkeologi permukiman, arkeologi demografi, dan arkeologi regional.

\section{Lanskap dalam Paradigma Pasca-Prosesual}

Kemunculan perspektif pasca-prosesual dalam arekologi tentu saja tidak terlepas dari kritik terhadap pendekatan prosesual yang dianggap terlalu memaksakan penggunaan metode sains sehingga mengabaikan faktor perkembangan sosial-budaya di tengah-tengah masyarakat. Paradigma ini berkembang tahun 1980-an, dipelopori oleh Ian Hodder bersama koleganya. Tokoh-tokoh yang dianggap penting atas kemunculan pasca-prosesual adalah Ian Hodder, Christoper Tilley, M. Shank, dan M. Leone.

Gagasan-gagasan penting dalam pandangan pasca-prosesual adalah: (1) menolak pandangan bahwa budaya sebagai sistem atau struktur, (2) adanya peran individu dalam membentuk kebudayaan, (3) kegiatan penafsiran dalam arkeologi sangat erat kaitannya dengan subjektivitas penafsir. Oleh sebab itu, tidak ada hal yang bersifat murni objektif, (4) konteks dari kebudayaan materi sangatpenting dan menentukan hasil penafsiran, (5) pengetahuan bersifat interpretatif dan khusus, sehingga menolak adanya generalisasi dan kebenaran tunggal, (6) adanya politik di balik ilmu, (7) pengetahuan masa lampau diperoleh dan dipakai untuk merekonstruksi masa kini, (8) membuka kesempatan untuk beragam penafsiran, (9) sangat memperhatikan makna dari budaya materi, (10) menggunakan metode induktif-deduktif (11) hermeneutika sebagai metode interpretasi (Hodder, 2005; Hodder \& Hutson, 2003). Pandangan-pandangan ini tentunya mempengaruhi pada studi arkeologi lanskap.

Bertolak pada pemikiran-pemikiran di atas, beberapa kaum pasca-prosesual mendefinisikan lanskap sebagai berikut: (1) lanskap sebagai 'konstruksi pikiran' (Johnson, 2007); semua lanskap dikonstruksi oleh manusia baik melalui aktivitas fisik (membangun sesuatu, melaksanakan, ritual tertentu) maupun melalui 
mitologi; lanskap tergantung dari interpretasi orang-orang yang tinggal di dalamnya (Layton \& Ucko, 1999); (5) lanskap tidak sama dengan lingkungan alam. Lanskap merupakan buatan (sintetik), dengan struktur sistem budaya dan interaksi organisai manusia dengan lingkungannya (Anschuetz, Wilshusen, \& Scheick, 2001); (6) ide atau konsep paling mutakhir tentang lanskap menekankan pada dimensi sosiosimbolik, bahwa lanskap merupakan entitas yang ada karena dikenali, dirasakan dan dikonseptualisasikan oleh masyarakat pendukungnya (Ashmore \& Knapp, 1999).

Dari pendapat-pendapat tersebut, kajian lanskap menurut pandangan pasca-prosesual menitikberatkan pada perspektif, subyektifitas, dan interpteratif (pemaknaan atau pun arti penting) terhadap budaya materialyang dihasilkan. Sebagaimana dijelaskan oleh Tanudirjo (2019) bahwa kajian lanskap dalam perspektif pascaprosesual terfokus pada: (1) unsur apa yang dipilih individu/kelompok manusia, (2) sudut pandang (perspektif) yang diambil individu/kelompok, (3) alasan individu/ kelompok manusia memilih unsur dan sudut pandang itu, (4) memahami gambar dari sudut pandang pelukis (makna dan konteks).

Di sisi lain, paradigma pasca-prosesual dikritik karena dinilai hasil interpretatif dan subyektifitas yang dihasilkan arkeolog terhadap material culture tidaklah sama. Tanudirjo dalam makalah "Arkeologi Pasca-prosesual: Alam Pikir Pascaprosual dalam Arkeologi", mengungkapkan bahwa pengetahuan yang subyektif tentu tidak bebas nilai seperti yang digagas oleh kaum positivis yang menjadi pendukung Arkeologi Prosesual. Sebaliknya, pengetahuan itu selalu mengandung 'politik budaya'. Artinya, nilai budaya orang yang menafsirkan akan terbawa dalam pengetahuan yang diperolehnya, dan apabila pengetahuan itu dipindahkan atau ditularkan kepada orang lain, maka si penerima akan terpengaruh oleh nilai budaya dari pembawa pengetahuan tadi. Dengan demikian, si penerima pengetahuan itu di-konstruksi pikirannya oleh si pembawa pengetahuan (Tanudirjo, 2019).

Ambiguitaspemaknaan dalam paradigmapascaprosesual merupakan hal yang tak dapat dipungkiri karena berangkat dari dasar subyektifitas tersebut. Untuk melengkapi proses interpretasi, Hodder menambahkan pendekatan fenomenologi. Fenomenologi berpijak pada subyektifitas dan pengalaman manusia dalam berinteraksi dengan material curlture tersebut. Sehingga peneliti atau arkeolog ditekankan untuk terlibat langsung dengan obyek material. Sebagaimana Tilley (2005) menjelaskan bahwa fenomenologi memfokuskan tentang cara seseorang memperoleh pengalaman dari berinteraksi dengan objek (dalam hal ini objek arkeologis) melalui pengindraan tubuhnya selama melakukan interpretasi.

\section{Lanskap Situs Gosari dalam Perspektif Prosesual dan Pasca-prosesual}

Kontradiksi paradigma prosesual dan pascaprosesual dalam melihat lanskap memang tidak perlu dipersoalkan lagi. Namun sinergitas keduanya menjadi pokok bahasan yang paling penting. Oleh karena itu, pada bagian ini akan dibahas bagaimana lanskap Situs Gosari Gresik dalam dua paradigma yang berbeda. Situs Gosari terletak di sebelah timur, kaki perbukitan kapur miosen akhir utara Jawa bagian timur (koordinat: 0660'9.6”; 112³0'26.4”E). Kondisi lingkungan Gosari saat ini lebih terkesan gersang dan tandus. Perbukitan kapur yang membentang utara selatan maupun timur - barat mengelilingi wilayah desa Gosari.

Tiga unsur penting Situs Gosari, yaitu situs tungku industri gerabah, dua sendang, dan prasasti Gosari (Butulan). Situs tungku industri 
gerabah terdapat di sisi Barat Daya Masjid Desa dan bersebelahan langsung dengan makam desa di sisi selatan. Di sisi barat laut situs tungku gerabah yang berjarak $122 \mathrm{~m}$ terdapat sendang 1 yang memiliki struktur batu putih yang dibentuk persegi. Mata air sendang tersebut berada tepat di sebelah jalan desa baru yang mengapit sisi selatan dan barat sendang. Posisi sendang 2, berada di sisi barat laut berjarak $205 \mathrm{~m}$ dari sendang 1 . Mengikuti jalan desa yang berjarak $342 \mathrm{~m}$ dari sendang 2, terdapat prasasti Gosari pada dinding pintu goa bukit kapur.

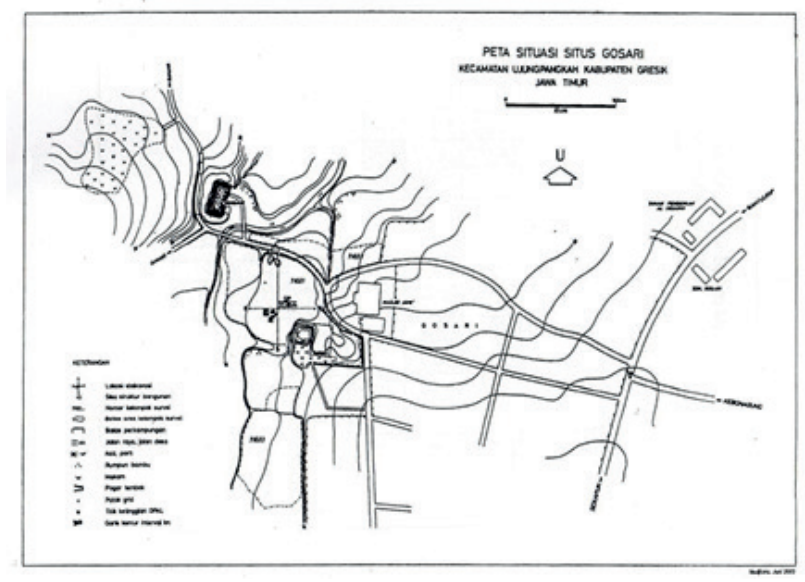

$$
\begin{gathered}
\text { Gambar 1. Peta situasi Situs Gosari } \\
\text { (sumber: Tim Peneliti Puslit Arkenas, (2005) }
\end{gathered}
$$

Hingga kini ditemukan empat bekas tungku pembakaran gerabah yang disusun secara berderat, dengan bentuk dasar serupa yakni elips, struktur ovaloid lebih kecil, terdapat parit $(40 \mathrm{~cm}$ x $20 \mathrm{~cm}$ ). Dinding tungku dibuat dari susunan batu gamping keras bentuk tidak beraturan; dilapis dengan tanah liat setebal 3-4 cm yang kemudian mengeras akibat pemanasan. Di bagian depan mulut tungku terdapat lapisan abu tebal bercampur atau didahului dengan lapisan pecahan tembikar. Sebagian dari dinding merupakan campuran tanah liat dan pecahan tembikar. Sebagian dari dinding merupakan campuran tanah liat dan pecahan tembikar (Peneliti, 2009: 4) lih. gambar 2.

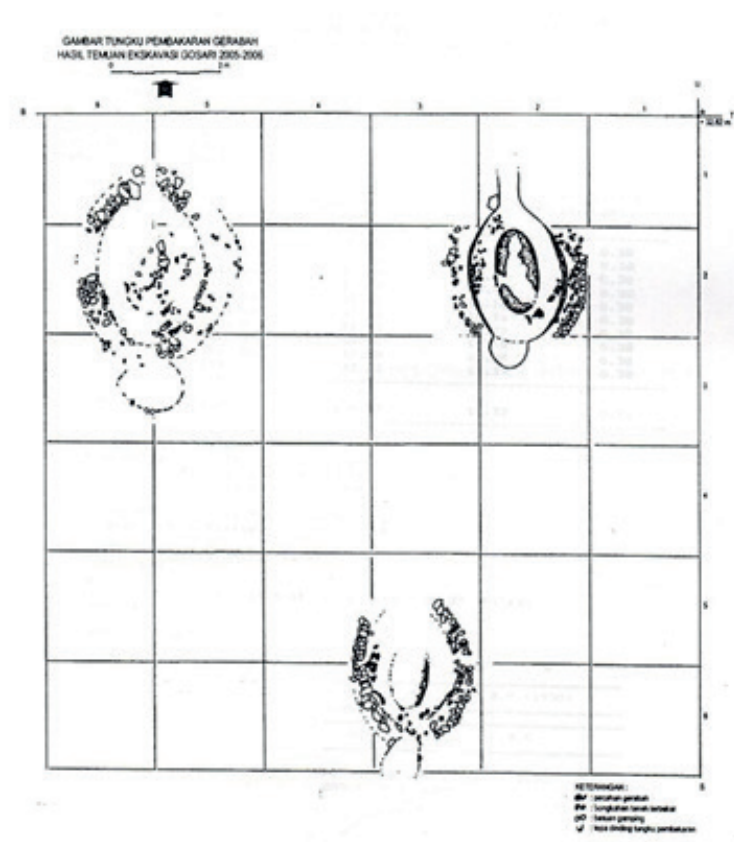

Gambar 2. Tiga Tungku pembakaran gerabah (sumber: Tim Peneliti Puslit Arkenas, (2006)

Produksi gerabah yang dihasilkan adalah kendi berceret (biasanya disebut kendi tipe Majapahit), botol mercuri, celengan, teko, dan cawan. Berjenis gerabah halus berwarna merah polish dan coklat kehitaman, sedangkan yang berwarna jingga berjenis gerabah kasar. Industri gerabah ini menggunakan teknik 'southeast asian ware' atau 'fine paste'. Ciri lainnya adalah terdapat hiasan memiliki ciri hiasan badan berbentuk bulat, dinding cukup tipis, dihiasi goresan, dan profil yang dibentuk menyerupai 'belimbing', dan dasarnya datar (Peneliti, 2006).

Sendang 1 berbentuk persegi panjang ( $5 \mathrm{~m}$ x10 $\mathrm{m})$, dinding kolam dari bata dengan kedalaman sekitar 1,5 m. Sedangkan sendang 2 berupa kubungan hampir membentuk lingkaran yang disusun atas batu kapur putih. Kini, sendang 2 telah mengalami perubahan berupa penambahan ruang bersekat. Sendang 1 difungsikan sebagai aktivitas pekerja, sedangkan sendang 2 digunakan sebagai sumber produksi industri gerabah (Peneliti, 2005). Unsur penting lainnya adalah prasasti Gosari (Butulan) yang berada di mulut goa kapur. Parasasti ini berkasara Hanacaraka dan 
bahasa Jawa Kuna, dengan angka tahun 1298 Saka (1376 M). Isi prasasti menyebutkan 'San(g) Rama Samadya yang mendiami tempat tersebut karena tersingkarkan'.
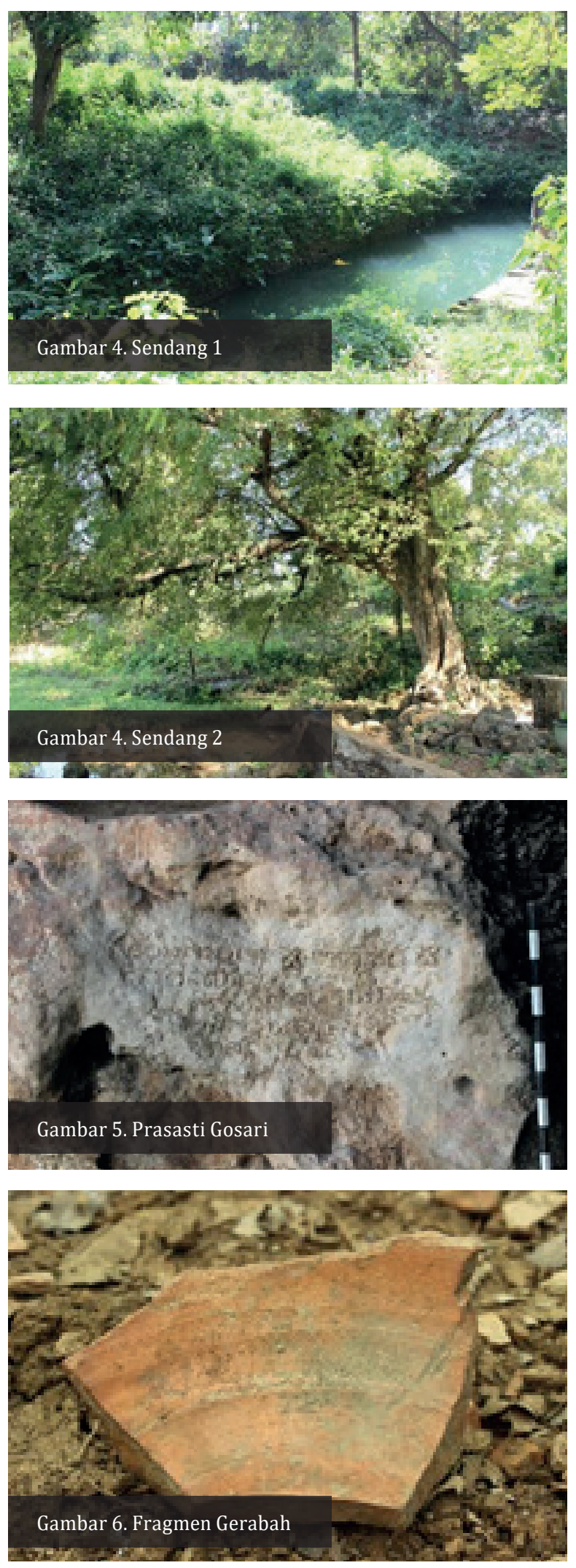

(sumber: Tim Pendaftaran Cagar Budaya Kab. Gresik (2017)
Selain tiga unsur penting di atas, temuan lain di sekitar Situs Gosari adalah fragmen gerabah yang tersebar dari tungku hingga goa prasasti, keramik Dinasty Song abad 12-14 M, fragmen periuk, kerangka manusia, molusca, dan makam-makam kuna (Peneliti, 2006).

Paradigma prosesual dalam lanskap Situs Gosari digunakan untuk mencari korelasi antar unsur-unsur fisik seperti pertanggalan, keletakan fisik, dan peranan hasil industri gerabah terhadap kondisi masyarakat masa lampau. Hasil penelitian Tim Peneliti Puslit Arkenas menunjukkan bahwa lanskap Situs Gosari dalam paradigma prosesual adalah sebagai berikut: Pertama, pertanggalan Situs Gosari diyakini sudah ada era Kerajaan Majapahit, yakni tahun 1376 M. Dibuktikan dari prasasti Gosari yang berangka tahun $1298 \mathrm{C}$ atau 1376 M (Peneliti, 2006). Kedua, model gerabah yang dihasilkan dikenal sebagai 'Majapahit Ware' karena terdapat persamaan dengan gerabah di Situs Trowulan, Situs Pondowolimo, Situs Lasem, dan situs-situs di sekitar Jawa Timur (Peneliti, 2006). Ketiga, keletakan situs tungku pembakaran dengan sendang 1 dan sendang 2 menunjukkan adanya korelasi yang terpusat pada sendang 2 sebagai pusat sumber air. Karena sendang 1 hanya digunakan untukaktivitas pekerja. Keempat, Gosari memiliki perananyang penting dalam perdagangan dan pengembangan teknologi industri, khususnya produk tembikar halus karena pendistribusiannya mencakup pusat-pusat permukiman yang lebih luas di abad 12-14 M (Peneliti, 2009).

Hasil penelitian prosesual hanya mampu menjelaskan lanskap Situs Gosari yang terbatas padaproduktivitasgerabahdanpendistribusiannya di masa lampau. Namun bagaimana keterkaitan dan posisi antara sendang, prasasti, tungku pembakaran gerabah, dan kondisi masyarakat sekitar tidak dijelaskan secara terperinci.

Dalam persepektif pasca-prosesual kali ini 
mencoba melengkapi keterbatasan hasil penelitian menggunakan paradigma prosesual. Penelitian ini berusaha melihat fenomena yang terjadi di msyarakat sekitar, terutama pandangan dan kepercayaannya. Khususnya mitologi sendang 2 yang masih dipercaya hingga saat ini. Sebagaimana dijelaskan oleh Hasan Sadiq ${ }^{1}$ bahwa masyarakat Gosari menyakini keberadaan sendang atau pancuran dalam dua perspektif. Pertama, sendang ini dikenal dengan nama Sendang Besawon, terkait asal mulanya. Menyebutkan sumber air ini berasal dari tongkat yang ditancapkan oleh Nur Imam Mudi (Mbah Besawon) setelah bertarung melawan Darmayudha.

Adu kekuatan atau peperangan dalam konteks masa klasik merupakan hal yang wajar dilakukan jika dianggap sebagai ancaman dan menganggu eksistensi individu maupun kerajaan. Sosok Mbah Besawon yang sakti dan baik sehingga sangat dihormati oleh masyarakat sekitar, dianggap mengganggu integritas Kerajaan Majapahit kala itu. Munculnya sumber air yang berasal dari tongkat yang ditancapkan, memberikan semangat kehidupan baru bagi masyarakat Gosari yang sebelumnya tidak memiliki sumber air. Persepsi masyarakat terhadap pemanfaatan sendang ini bukan lagi semata-mata sebagai sumber air, namun dimaknai sebagai bentuk penghargaan kepada Mbah Besawon yang telah berjasa.

Kedua, dikenal sebagai Sendang Bidadari, terkait dengan peranan atau keberkahannya. Folklor setempat mengatakan bahwa sendang ini merupakan tempat bidadari mandi. Dari narasi tersebut, muncul tradisi 'pagi kawitan' dan 'tapa kumkum'. Pagi kawitan memunculkan jargon "sopo sing adus banyu perawan dadi ayu" (siapa yang mandi air perawan, maka akan memiliki wajah yang cantik). Ritual ini dilaksanakan oleh para gadis sebelum matahari terbit. Dalam hal ini, banyu perawan merujuk pada kemurnian air pada malam hari dan bekas bidadari mandi yang dapat memancarkan kemurnian jiwa dan perwajahan bidadari sebagai perempuan cantik. Air dipagi hari dipersepsikan sebagai air yang murni karena belum terkontaminasi oleh kegiatan manusia pada siang hari sehingga dapat memancarkan kebaikan bagi yang menggunakannya. Sedangkan tapa kumkum dilakukan dengan cara berendam di sendang sekaligus berdoa (menurut kepercayaan masing-masing), waktu pelakasanaan adalah malam hari hingga menjelang matahari terbit. Ritual ini dilaksanakan dengan tujuan untuk mendapatkan kekuasaan, kekayaan, dan keinginan profan maupun spiritual lainnya. Mereka percaya bahwa kemurnian air dari sendang tersebut mampu memberikan energi positif sehingga tercapainya keinginan atau hajat. Hingga saat ini tapa kumkum masih dilakukan masyarakat yang mempercayainya.

Berkembangnya kepercayaan 'pagi kawitan' dan 'tapa kumkum' dengan Sendang Bidadari, pada dasarnya sebagai bentuk representasi etos kerja masyarakat Gosari yang tinggi. Aktivitas seharihari diawali sebelum matahari terbit, baik dalam hal pertanian maupun industri gerabah. Sehingga wajar jika industri ini mampu menghasilkan gerabah dalam jumlah yang besar dengan distribusi yang luas.

Hal menarik lainnya adalah keberadaan sendang (2) yang digunakan sebagai penopang industri gerabah. Mengapa sendang (1) hanya digunakan sebagai aktivitas pekerja misalnya untuk mandi, bukan sebagai bahan pelengkap gerabah? Padahal posisinya lebih dekat dengan aktivitas industri gerabah. Sebagaimana diyakini oleh masyarakat Jawa pada umumnya, dalam melakukan kegiatan produksi yang berhubungan dengan kelangsungan hajat hidup orang banyak, maka akan dipilih bahan-bahan terbaik. Misalnya bercocok tanam, kecenderungan masyarakat Jawa 
untuk menggunakan air yang berasal dari sumber terbaik semata-mata sebagai pengharapan hasil panen dengan kualitas terbaik. Sama halnya dalam industri gerabah Gosari. Pilihan sendang (2) terkait dengan kepercayaan yang melekat diharapkan membawa kebaikan dan meningkatkan kualitas serta produktivitas gerabah.

Dari kasus Situs Gosari, paradigma pascaprosesual dapat mendeskripsikan relasi lanskap dan obyek arkeologis lebih mendalam. Terkadang, satu tinggalan arkeologi saja dapat memberikan serangkaian interpretasi. Contohnya relasi sendang (2) dalam memahami lanskap Situs Gosari. Melalui paradigma pasca-prosesual, sendang (2) tidak hanya dilihat fungsinya sebagai sumber air yang digunakan sehari-hari dan penopang industri gerabah, namun juga disakralkan. Dari kajian tersebut, dapat diketahui bahwa sisa-sisa budaya tak bendawi klasik masih terpelihara oleh masyarakat sekitar bahkan dari luar daerah Gosari. Meski tanpa mereka sadari, sisa kepercayaan itu berkesinambungan dengan munculnya agama Islam yang telah mengubah dasar kepercayaan mereka. Pasca-prosesual memberikan keleluasaan dalam berbagai pemaknaan terhadap lanskap suatu obyek arkeologi. Hal ini terkait dengan sifat dasarnya yang menitikberatkan pada persoalan relasi antar manusia (humanis).

\section{Kesimpulan}

Berdasarkan pembahasan diatas diketahui perbedaan antara paradigma prosesual dan pasca-prosesual dalam melihat lanskap arkeologi. Lanskap dalam perspektif prosesual lebih menekankan pada unsur-unsur indrawi untuk mejelaskan lanskap fisik maupun budayanya. Sedangkan pandangan pasca-prosesual lebih menekankan interpretasi terhadap gejala-gejala yang melingkupi obyek arkeologi, baik hal-hal yang berhubungan dengan alam maupun perubahan atau perkembangan individu maupun masyarakat pendukung.

Dari paradigma prosesual diperoleh lanskap Situs Gosari berupa kondisi alam, produktivitas, distribusi industri gerabah, dan keterkaitan antar unsur-unsur penting dalam situs yakni tungku pembakaran, dua sendang, dan prasasti. Sedangkan pandangan pasca-prosesual lebih menekankan pemaknaan terhadap obyek arkeologis yang diperoleh dari folklor yang berkembang. Dari pandangan ini dapat diketahui bahwa lanskap budaya terhadap kepercayaan terhadap mitologi masih dipertahankan. Hal ini menunjukkan bahwa, tanpa disadari tinggalan budaya tak bendawi masa klasik masih terpelihara dengan baik meski terdapat perbedaan semangat zaman yang signifikan.

Sinergitas dari kedua paradigma tersebut menghasilkan pandangan lanskap yang bermacammacam. Namun heterogenitas ini dipandang sebagai kekayaan data arkeologis. Semakin banyak data yang diperoleh, maka semakin banyak peluang untuk mendeskripsikan Situs Gosari dalam konteks masa lampau yang mendekati aslinya.

\section{Daftra Pustaka}

Anschuetz, K., Wilshusen, R., \& Scheick, C. (2001). An Archaeology of Landscapes:

Perspectives and Directions. Journal of Archaeological Research, 9(2). https://doi. org/10.1023/A:1016621326415

Ashmore, W., \& Knapp, B. (1999). Archaeologies of Landscape: Contemporary Perspectives. United Kingdom: Blackwell Publishers Ltd.

Earle, T. K., Preucel, R. W., Brumfiel, E. M., Carr, C., Limp, W. F., Chippindale, C., ... Zeitlin, R. N. (1987). 
Processual Archaeology and the Radical Critique [and Comments and Reply]. Current Anthropology, 28(4). https://doi.org/10.1086/203551

Gosden, C., \& Head, L. (1994). Landscape - a Usefully Ambiguous Concept. Archaeology in Oceania. https:// doi.org/10.1002/arco.1994.29.3.113

Greene, K. (2003). Archaeology An Introduction. United Kingdom: Routledge.

Hodder, I. (1991a). Interpretive Archaeology and Its Role. American Antiquity, 56(1). https://doi. org/10.2307/280968

Hodder, I. (1991b). Post-modernism, Post-structuralism, and Post-processual Archaeology. In The Meanings of Things: Material Culture and Symbolic Expression (pp. 64-78). New York: Harper Collins Academic.

Hodder, I. (2005). Postprocessual and Interpretive Archaeology. In C. Renfrew \& P. Bahn (Eds.), Archaeology The Key Concepts (pp. 155-159). New York: Routledge.

Hodder, I., \& Hutson, S. (2003). Reading The Past: Current Approaches to Interpretation in Archaeology

(Edition 3). United Kingdom: Cambridge University Press.

Hudson, C. M. (2008). Walter Taylor and the history of American archaeology. Journal of Anthropological Archaeology, 27(2). https://doi.org/10.1016/j.jaa.2008.02.001

Johnson, M. (2007). Ideas of Landscape. United State: Blackwell Publishing Ltd.

Kemendikbud, C. B. (2017). Situs Gosari. Retrieved from Sistem Registrasi Nasional Cagar Budaya website: http://cagarbudaya.kemdikbud.go.id/cagarbudaya/detail/P02017082100014/situsgosari

Layton, R., \& Ucko, P. (1999). The Archaeology and Anthropology of Landscape: Shaping Your Landscape. Routledge.

Mundardjito, M. (2007). Paradigma dalam Arkeologi Maritim. Wacana, Journal of the Humanities of Indonesia, 9(1). https://doi.org/10.17510/wjhi.v9i1.229

Peneliti, T. (2005). Laporan Penelitian Arkeologi Teknologi Industri Tembikar Halus di Wilayah Ujung Pangkah Gresik Jawa Timur (Tahap I). Jakarta.

Peneliti, T. (2006). Laporan Penelitian Arkeologi Teknologi Industri Tembikar Halus di Wilayah Ujung Pangkah Gresik Jawa Timur (Tahap II). Jakarta.

Peneliti, T. (2009). Laporan Penelitian Arkeologi Teknologi Industri Tembikar Halus di Wilayah Ujung Pangkah Gresik Jawa Timur (Tahap III). Jakarta.

Sabloff, J. (2005). Processual Archeology. In C. Renfrew \& P. Bahn (Eds.), Archaeology The Key Concepts (pp. 159-164). New York: Routledge.

Sunliensyar, H. H. (2018). Lanskap Arkeologi Dalam Perspektif Prosesual Dan Pasca-Prosesual: Studi Kasus Kompleks Megalitik Di Dataran Tinggi Jambi. Berkala Arkeologi, 38(2). https://doi. org/10.30883/jba.v38i2.267

Tanudirjo, D. A. (2019). Arkeologi Pasca-Prosesual Alam Pikir Pasca-Modernisme Dalam Arkeologi. In Makalah Bahan Ajar. Yogyakarta: Universitas Gadjah Mada.

Tilley, C. (2005). Phenomenological Archaeology. In C. Renfrew \& P. Bahn (Eds.), Archaeology The Key Concepts (pp. 151-165). New York: Routledge.

Utomo, D. W. (2012). Gresik: Sebuah Catatan Perjalanan Sejarah. Retrieved November 30, 2019, from 
Ikatan Ahli Arkeologi Indonesia website: https://iaaipusat.wordpress.com/2012/03/19/ gresik-sebuah-catatan-perjalanan-sejarah-islam/

Webster, G. (2008). Culture History : A Culture-Historical Approach. In Handbook of Archaeological Theories.

Winarto, Y. T. (2014). Pendekatan Prosesual: Menjawab Tantangan dalam Mengkaji Dinamika Budaya. Antropologi Indonesia, 0(60). https://doi.org/10.7454/ai.v0i60.3354

Wylie, A. (2002). Thinking From Things: Essays in The Philosophy of Archaeology. London: University of California Press.

Wawancara Hasan Sadiq (Sekretaris Kecamatan Sidayu, Tokoh Masyarakat Gosari) tanggal 27 Desember 2019

1 Sekretaris Kecamatan Sidayu, sekaligus tokoh masyarakat Desa Gosari. Data diperoleh dari hasil wawancara tanggal 28 Desember 2019. 